\title{
THE EUROPEAN CONVENTION FOR THE PROTECTION OF HUMAN RIGHTS AND FUNDAMENTAL FREEDOMS
}

\begin{abstract}
Although the concept of internationally protected human rights can be traced to Grotius, ${ }^{1}$ it has only been since the Second World War that any significant steps have been taken to create such rights. This has been accomplished through the growth, during the last fifteen years, of regional and international organizations which have introduced new approaches to the role of the individual vis-à-vis international law, and to the relationship of States to supra-national institutions. On a regional level, a significant advance has been made by the Council of Europe. Organized in 1949 by ten States in Western Europe, the purpose of the Council is to "achieve a greater unity between its Members for the purpose of safeguarding and realising the ideals and principles which are their common heritage and facilitating their economic and social progress."2

In the past ten years the Council of Europe has furthered cooperation between its member nations, now totaling fifteen, by preparing and recommending to them a number of Conventions relating to problems which could not be adequately handled on a national level. The major achievements of the Council have not been in the economic sphere, however, because of differences in economic policy between the United Kingdom and the Scandinavian countries on the one hand and the continental States on the other. ${ }^{3}$ The cohesive force is not therefore, a likeness of economic interest, but is rather a response to an external pressure common to all -the expanding threat of communism. This threat has been met on the economic and inilitary levels by the Organization for European Economic Cooperation which administered the Marshall Plan, and by the North Atlantic Treaty Organization. In the late forties the need for an ideological front manifested itself in the creation
\end{abstract}

1 H. LaUterpacht, International Law and Human Rights 117-18 (1950).

${ }^{2}$ Statute of the Councir of Europe, art. 1(a). The institutional makeup of the Council of Europe consists of two organs, a Committee of Ministers and a Consultative Assembly. The Committee of Ministers consists of the Foreign Minister, or an alternate, of each of the fifteen Member States. The Committee has the final responsibility for achieving "greater unity" among Members through the preparation of recommendations to Members and the conclusion of Conventions which are then submitted to the Members for ratification. RoBerTson, THE Councr OF EUROPE 30 (1956).

The Consultative Assembly consists of 135 representatives drawn from the Members, roughly according to population. The makeup of the Assembly is an innovation in international organizations in that the representatives are not governmental officials "acting on the instructions of their governments, but members of Parliament, acting in an individual capacity." ROBERTSON, op. cit. supra at 9 . This concept of a parhamentary body has been copied by several other European regional institutions. See, e.g., Treaty Establishing the European Coal and Stecl Community, art. 21 in 1 EUROPEAN YEARBOoK 371 (1955), and the Treaty Establishing the European Economic Commumity, art. 138 in 4 EUROpEan Yearbook 497 (1958).

The primary function of the Consultative Assembly is to provide a forum to express and formulate public opinion in Western Europe. Within the organizational structure of the Council, the Consultative Assembly is to discuss, debate, and then inake recommendations to the Committee of Ministers on any matter within the scope of the Council. RoBersson, op. cit. supra at $46-47$.

3 Mackay, Strasbourg in Perspective, 4 European Yearbook 174, 177-78 (1958); Sørensen, The Council of Europe, in YearbooK of Wordd AfFaIRs 75, 78-79 (1952); The Christian Science Monitor, Sept. 30, 1960, p. 14, col. 3. 
of the Council of Europe. ${ }^{4}$ And it is this ideological impetus behind the Council which has led to what is perhaps its major achievement, the European Convention for the Protection of Human Rights and Fundamental Freedoms.

By 1949 it became evident that the human rights activities of the United Nations were to be compromised at the lowest level of controversial principlesmere statements of rights without legal effect or effective means of implementation. ${ }^{5}$ Although the memory of Nazi brutalities and the fear of communism contributed to the idea, it was probably this frustration of the United Nations Commission on Human Rights which precipitated the decision to establish a procedure within the Council of Europe to ensure the protection of human rights. A Convention which defined substantive rights and created a supra-national mechamism to guarantee these rights was signed in Rome by the Council's Committee of Mimisters in 1950 and was thereafter submitted to the Member States for ratification. After a Protocol in 1952 added property, education, and election rights, ratification proceeded rapidly, and the Convention became effective on September 3, 1953. ${ }^{6}$ As of February, 1961, the Convention and Protocol have been ratified by the following members of the Council of Europe: Austria (1958); Belgium (1955); Denmark (1953); Federal Republic of Germany (Convention 1952, Protocol 1957); Greece (1953); Iceland (1953); Ireland (1953); Italy (1955); Luxembourg (1953); the Netherlands (1954); Norway (1952); Sweden (Convention 1952, Protocol 1953); Turkey (1954); and the United Kingdom (Convention 1951, Protocol 1953). ${ }^{7}$ France, one of the originators of the Council of Europe, remains the only Member which has not become a party to the Convention. ${ }^{8}$

I

THE CONVENTION: SUBSTANTIVE RIGHTS

In its grant of substantive rights, the first section of the Convention guarantees the inviolability of life and outlaws torture, slavery, forced labor and exile. ${ }^{9}$ The individual's right to freedom of thought, conscience, religion, ${ }^{10}$ association, and peaceful assembly are recognized, ${ }^{11}$ as is a freedom from interference with private and family life. ${ }^{12}$ The Convention further recoginzes a right to marry and found a family. . $^{13}$

${ }^{4}$ N.Y. Times, Aug. 10, 1949, p. 20, col.5; id., Aug. 11, 1949, p.1, col.2; Sørenson, The Council of Europe, in YEARBOOK OF WORLD AFraIrS 75, 770 (1952).

5 ROBERTSON, THE COUNCIL OF EUROPE 146-47 (1956); Martin, Human Rights and World Politics, in Yearbook of Wordo Afratrs 37, 48 (1951); Beaufort, Some Remarks About the European Convention for the Protection of Human Rights and Fundamntal Freedoms, 6 NEDERLANDS TIJDSCHRIFT VOOR INTERNATIONAI RECHT 42, 43 (1959).

6 The text of the Convention and Protocol can be found in 1 European Yearbook 317-43 (1955); 45 Axr. J. InT's L. Supp. 24 (1951) (Convention); European Comar's of HuMan Rights, Documents and Decistons 4-40 (1959) [hereinafter cited as Docunents and DEcrsrons].

7 Europe Today and Tomorrow, September 1953, p. 11; Docunnents and Decrstons 54-55. The Saar, which became a part of the Federal Republic of Germany in 1957, had ratified the Convention and Protocol in 1953.

8 This is attributable in part to French troubles in Algeria and mainly to a bitter churchstate dispute over the education of French youth. The Christian Science Monitor, March 27, 1958 , p. 11, col. 4 ; id., Jan. 26, 1959, p. 2, col. 5.

8 The European Convention on Human Rights, arts. 2, 3, 4.

10 Art. 9.

11 Art. 11.

12 Art. 8.

13 Art. 12. 
Since human and civil rights can be secured only by fair procedures under the laws of Member Nations, the first section guarantees a right to freedom from arbitrary arrest and provides for prompt arraignment and a summary action to test the legality of the interument. It also creates a cause of action for arrests and confinements in violation of these provisions. ${ }^{14}$ All persons are guaranteed a "fair and public hearmg within a reasonable time by an independent and impartial tribunal established by law."15 In a criminal prosecution, the defendant is accorded the presumption of innocence, a right to confront lostile witnesses, and, if indigent, free legal assistance. ${ }^{16}$ This section contains a further provision prohibiting the ex post facto application of criminal laws and sanctions. ${ }^{17}$

The Convention itself does not guarantee a right to property, education, or free elections. These riglts were proposed by the Consultative Assembly to the Committee of Ministers, but no agreement liad been reached as to their nature or scope when the Convention was adopted in 1950.18 After two years of study in which the Council tried to plirase an education clause that would not run afoul of church-state controversies and a property rights provision that would be acceptable to the Socialist governments, the Protocol in $1952^{10}$ gave individuals a right to the peaceful enjoyment of their possessions, ${ }^{20}$ a right to free elections, ${ }^{21}$ and a guarantee to be free from state imterference with their education. ${ }^{22}$

In a broad statement of the equality of man, article 14 of section 1 insures the enjoyment of these rights by all, irrespective of race, color, sex, national origin, or pohtical or religious opinion, thus supplementing article 1 which states that the Convention is to apply to all persons within the jurisdiction of the Contracting Parties. After some debate, it was decided that the Convention would apply to territories for whose international relations Member States were responsible only upon the express consent of the Contracting Parties. ${ }^{23}$ Declarations of extension have been filed by Deumark, the Netherlands, and the United Kingdom. ${ }^{24}$

The first section of the Convention contains provisions for the derogation of the riglits conferred ${ }^{25}$ when necessary for national security, public safety, or for the protection of health and morals. These escape clauses, coupled with the carte blanche power of the Contracting Parties when dealing with the political rights of aliens, ${ }^{26}$ and the general derogation clause in the case of "war or public emergency"27 have caused some criticism of the Convention. Moreover, critics

14 Art. 5.

15 Art. 6(1).

16 Art. 6(2) and (3).

17 Art. 7.

18 Robertson, The European Convention on Human Rights: Recent Developments, 28 BRIT. Yв. INT'L L. 359, 360 (1951).

${ }^{10} I d$. at 361 .

20 Protocol, Art. 1.

21 Protocol, Art. 3.

22 Protocol, Art. 2.

23 Art. 63(1).

24 In 1953, Denmark made the Convention and Protocol applicable to Greenland; in 1955, the Netherlands extended these rights to Surinam and the Antilles; and in 1953, the United Kingdom extended the Convention, but apparently not the Protocol, to some 43 territories. DoctrMEnts AND Decisions $45-47$.

${ }_{25}$ Article 15 pernits Member Parties to derogate from all obligations under the Convention with the exception of freedoin from torture, slavery, deprivation of life, and the retroactive application of criminal laws and sanctions.

26 Art. 16.

27 Art. 15. 
point out that the Convention does not provide for international recognition of domestic divorce and marriage provisions, nor does it abolish legislation prohibiting miscegenation. It is further noted that unlike the Universal Declaration of Human Rights, the Convention does not grant a right of asylum or a right of exit.28

While these criticisms are vahid, one is reminded of the experience of the Umited Nations Committee on Human Riglits, which perlraps granted these riglits "not wisely, but too well." The Convention represents a compromise between the advocates of national sovereignty on the one hand and the staunch supporters of a European federation on the other. The federalists recognized that if a meaningful implementation procedure were to be adopted, national imterests could not be rendered completely subservient to those of the individual. Thus, while the derogation and escape clauses cannot be overlooked, it would be unfair to conclude that the entire Convention is enveloped in their penumbra.

Although expressly permitted by the Convention, the use of reservations to the Protocol and the Convention lias been himited. ${ }^{29}$ Ireland approved the right of the indigent criminal defendant to free legal aid only insofar as it was already furnished. The Federal Republic of Germany accepted article 7, forbidding the retroactive effect of crimimal legislation, to the extent it was consistent with existent legislation. Norway excepted Jesuits from the coverage of article 9 (freedom of thought, conscience, and religion), since they had been banned from the country by the Constitution of 1814 . Here the Convention can well credit itself with being the moving force belind a 1956 amendment to the Norwegian Constitution wlich abolished the discriminatory treatment of Jesuits, and resulted in the revocation of the reservation..$^{30}$

By far the most troublesome obstacle to state ratification las been article 2 of the Protocol, which provides that, "in the exercise of any functions which it assumes in relation to education and to teaching, the State sliall respect the right of parents to ensure suclı education and teaching in conformity with their own religious and plilosophical convictions." The United Kingdom accepted this only "so far as it is compatible with the provision of efficient instruction and training, and the avoidance of unreasonable public expenditure." 31 Greece maintamed that article 2 would apply only to the extent that the term "philosoplical" conformed witl internal legislation. ${ }^{32}$ Sweden provided that a Clristian education could be replaced only by an acceptable substitute. ${ }^{33}$ Turkey's reservation was that this article would not affect local laws dealing with the unification of Turkish education. $^{34}$ Indeed, this provision alone is largely responsible for the failure of France to ratify the Convention. ${ }^{35}$

28 Green, The European Convention on Human Rights, 5 WorLd AFraIRs 432, 437-44 (1951). Rights to freedom of movement, exit from one's country, and entry into another are being considered for addition to the Convention. Consultative Assembly Recommendation No. 234, Jan. 1960.

29 Robertson, The European Convention on Human Rights: Recent Developments, 29 BRIT. Yв. INT'L L. 452, 454 (1952) ; Docunants AND Decisions 40-45.

30 Waldock, The European Convention for Human Rights, 34 BRIT. YB. INT'工 L. 356 (1959); DOCUMENTS AND Decisions 42. In addition, Luxembourg has made a reservation with respect to article 1 of the Protocol (right to possess property).

31 Docunants and Decisions 45.

321 EURopean Yearbook 343 (1955); DocunaENTS aNd Decisions 44.

33 DocUMENTS AND DECISTONS 44.

34 Documents and Decisions 43; Robertson, The Counctl of Europe 161 (1956).

35 See note 8 supra. 
Except for these reservations, however, the Convention guarantees fundamental rights and freedoms to all persons within the jurisdiction of the fourteen Contracting Parties, a total of over $236,000,000$ people. ${ }^{36}$

\section{II}

\section{THE CONVENTION: ENFORCEMENT PROCEDURE}

In the words of a former Swedish Minister of Foreign Affairs, "something new has taken place when the human rights are inscribed in international diplomatic instruments and when they are safeguarded by special institutions. ${ }^{137}$ The remarkable thing about the Convention is not so much that fourteen nations have agreed upon the definition of certain human rights, but that these nations have entered into legally binding treaties to respect these rights and have created certain supranational institutions to ensure adherence to these obligations. The failure of the United Nations to achieve any meaningful policy with respect to human rights came about not so much from disputes over their substantive content, as from conflicting views of the methods needed to enforce these rights. While the Universal Declaration of Human Rights ${ }^{38}$ is in some respects broader than the European Convention, the failure of the members of the U.N. to cede any of their sovereign powers to a supervisory body has rendered the Declaration "devoid of any legally binding force ... a landmark of retrogression rather than progress . ..."30

\section{A. Individual and Inter-State Petitions}

The enforcement procedure within the Council of Europe involves the Commission of Human Rights, the Court of Human Rights, ${ }^{40}$ and the Committee of Ministers. When there is a claim that a Member State has violated an obligation assumed under the Convention, the initial step is the submission of a petition to the Commission of Human Rights, which investigates the claim and tries to achieve a friendly settlement of the dispute. If this cannot be done, a report is prepared by the Commission which is then submitted to the Committee of Ministers. The final decision is then made by the Committee of Ministers or by the Court, depending, in turn, upon whether the question involved is political or legal in nature.

Two classes of petitions may be maintained under the Convention. The first class is the inter-State petition, whereby one of the High Contracting Parties submits, through the Secretary-General of the Council, an allegation of a breach by another Member Party. ${ }^{41}$ The second is the individual petition, which is addressed to the Secretary-General by "any person, non-governmental organisation or grontp of individuals claiming to be the victin of a violation by one of the High Contracting Parties of the rights set forth in this Convention. . . ."42

36 The Internationat Yearbook and Statesaran's Who's Who (1960).

37 The Christian Science Monitor, September 5, 1958, p. 2, col. 4.

38 U.N. GEN. Ass. OFF. REC. 3d Sess. 71-77 (A/810) (1948).

39 Martin, Human Rights and World Politics, in Yearbook OF WorLd AFFaIrs 37, 40 (1951). See also Moskowitz, Human Rights ANd Wordd Order 63 (1958).

40 Article 19 of the Convention, which establishes the machinery for enforcement, reads: "To ensure the observance of the engagements undertaken by the High Contracting Partics in the present Convention, there shall be set up: (1) A European Commission of Human Rights hereinafter referred to as 'the Commission'; (2) A European Court of Human Rights, hereinafter referred to as "the Court'."

41 Convention, Art. 24.

42 Convention, Art. 25. (Emphasis added.) 
The existence of an individual petition is a significant departure from the classical principles of international law, which restricted standing before international tribunals to States, and is a major achievement of the Convention. The object of the Convention is not to protect the rights of States, but of individuals. It is the individual, therefore, who needs a remedy to enforce these rights, for the case will be rare indeed where a State will gratuitously pick a quarrel with an ally as to the ally's treatnent of its own nationals. Furthermore, the individual petition tends to obviate the most apparent flaw of the inter-State petition, i.e., the interjection of pohtical issues in a problem involving the legal rights of an individual. ${ }^{43}$ The right of individual petition found in the European Convention is thus a significant advance beyond the proposed Covenants for the enforcennent of the United Nations Declaration of Human Rights, which allow only a contracting State to bring another State before the United Nations for an alleged violation of a person's rights. ${ }^{44}$

However, the individual petition was not viewed in this light by all nations who participated in the preparation of the Convention. A significant bloc led by the United Kingdom opposed this degree of cession of sovereignty to the Council. The resultant compromise has placed some limitations upon the right of an individual to petition. To answer the argument that the petition would be used for propaganda and harassment purposes, article 27(2) provides that the Commission shall "consider inadmissible any petition submitted under Article 25 which it considers incompatible with the provisions of the present Convention, manifestly illfounded, or an abuse of the right of petition." And the individual petition, like the inter-State complaint, may be considered by the Commission only "after all domestic remedies have been exhausted, according to the generally recognized principles of international law ...." 45

43 For example, early in 1960 a group of Africans from Nyasaland visited Iceland with the avowed, but unsuccessful, purpose of trying to persuade Iceland to bring Britain before the Commission of Human Rights for infringing human rights in Nyasaland. Significantly, this was just at the time when Iceland and Great Britain were fighting over fishing rights off of Iceland. The Economist, Feb. 27, 1960, p. 794-95. See also United Nations Review, July 1955, p. 38; Robertson, The CouncIL of Europe 152-54 (1956); Mossowitz, op. cit. supra note 39, at 108-10.

To overcome the difficulty of inducing a State to institute charges against another State, in 1956 it was suggested by the Committee on Legal and Admmistrative Questions of the Consultative Assembly that the Council adopt the "collective anonymity" procedure used by the League of Nations. That is, when an individual petition was received that was directed against a State which had not accepted the individual petition competence of the Commission, it would be referred to the President of the Commission. Then he and two other Commissioners, chosen by lot, would determine whether the petition should be admitted. In this way no one State could be considered to have committed an unfriendly act. See RoBertson, TrE CouncIr of EURope 167 (1956). This proposal was rejected by the Committee of Ministers. Robertson, The European Court of Human Rights, 9 AM. J. Comp. L. 1, 12 n.37 (1960).

44 Compare article 40, Draft Covenant on Civil and Political Rights [U.N. EcoSoc CounCrL OFF. Rec. 18th Sess., Supp. No. 7, 62-72 (E/2573 (1954) ], with article 33, Treaty Establishing the European Coal and Steel Cominunity, in 1 European Yearboor 375 (1955) and article 175, Treaty Establishing the European Community, in 4 European Yearbook 509 (1958). See also Horvath, The European Court of Human Rights, 5 ÖSTERREISCHISCHE ZEITSCERTFT Für ÖFFENTLICHES RECHT 166, 168 (1953).

45 Art. 26. Exhaustion of local remedies refers to the principle that a state against whom an international action has been brought for injuries suffered by private persons can prevent adjudication by the international tribunal if the aggrieved person has not first exhausted all possible renredies available to him under the domestic law of the defendant-state. Ambatielos (Greece-United Kingdom 1956) in Green, Internattonal Law THEOUgH THE Cases 597, 605 (2d ed. 1959). See also Fimnish Vessels Arbitration, [1933-34] Ann. Dig. 231 (No. 91). The phrase "generally recognized principles of international law" in article 26 was intended to in- 
The major inroad upon the right of individual petition is the statement in article 25 that such petition can be lodged only against a Contracting Party who "has declared that it recognises the competence of the Commission to receive such petitions." Thus far, Austria, Belgium, Denmark, the Federal Republic of Germany, Iceland, Ireland, the Netherlands, Luxembourg, Norway and Sweden have given this competence to the Commission. ${ }^{46}$ Greece, Italy, Turkey, and the United Kingdoin have not.

When the Commission receives an inter-State or individual petition of grievances, its first function is to determine admissibility. In the case of an inter-State petition this is done by written and oral arguments by the Parties involved.47 Where individual petitions are involved, admissibility is considered by a special three-man subcommittee. ${ }^{48}$ The subcommittee will look to the individual's file as a whole and will not regard the applicant as being bound by his "pleadings." Moreover, the subcommittee can, on its own initiative, request other documents and exhibits to aid in determining admissibility. ${ }^{49}$ If the petition of an individual is allowed, it is then turned over to a seven-man subcommittee which has the power both to call hearings and to investigate at the scene of the alleged violation, and the ultimate duty of achieving a friendly settlement of the dispute. ${ }^{50}$ If this cannot be accomplished a report is submitted to the entire Commission which may loold additional hearings and investigations, again with the view of effecting a friendly settlement.

\section{B. The Committee of Ministers}

If a friendly settlement is not achieved, a report with the Commission's recommendations is sent to the Committee of Ministers and to the defendant state.51 Then, if the case is not referred to the European Court of Human Rights within three months, a decision will be made by the Committee of Ministers as to whether there is a violation of the Convention. ${ }^{62}$ As another indicium of the partial cession of national sovereignty under the Convention it is to be noted that the decision of the Committee of Mimisters, which the Party States are obligated to recognize as binding, is to be taken by a two-thirds vote with no veto powers. ${ }^{53}$

\section{The Commission on Human Rights}

The first Commission on Human Rights was elected by the Cominittee of Ministers from names submitted by the Consultative Assembly and consisted of six

clude instances when exhaustion is not necessary, i.e., when the local courts have no jurisdiction to grant the relief requested; when resort to a local court would be a futile and empty gesture; and when the local court has purposely delayed adjudication of the case. ScEWARzENBEROER, INTERNATIONAI LAW 235-36 (2d ed. 1949).

46 Council of Europe News, July 1960, p. 5; id., September 1960, p. 4.

47 Rules of Procedure of the European Commission of Human Rights, in Documents AND Decistons 58-86.

48 Rule 45. Note, The European Commission on Human Rights, 50 Asr. J. INr's L. 949 (1956).

${ }_{49}$ McNulty and Eissen, The European Commission of Human Rights: Procedure and Jurisdiction, 1 J. INT'L COMCS. OF JURISTS 198, 201 (1958).

50 Rules 50-61. Documents AND Decisions 79-83. As of December, 1957, with the exception of Austria, all members of the Council of Europe, including France, had signed an agreement relating to the privileges and immunities of the Commissioners when in the various countries on Council business. Docuncents and Decisions 86-91.

61 Art. 31.

52 Art. 32.

53 Europe Today and Tomorrow, September 1953, p. 11. 
judges or ex-judges, six law professors, two practicing lawyers, and one legal advisor. In the first five years of its existence, 1955 to 1960 , the Commission dealt with three inter-State petitions and over 400 individual petitions.

Two of the inter-State petitions were lodged by Greece against the United Kingdom and arose from Britain's activities on Cyprus. ${ }^{54}$ The first complaint, dealing with the necessity of British "emergency" legislation, was filed in 1956. In 1957 the second Greek application cited some forty-fine instances of torture, for which the British Government was alleged to be responsible. The 1956 petition and twenty-nine cases from the 1957 petition were held admissible. A subcoumittee was dispatched to Cyprus, where it was active in peace negotiations and was instrumental in freeing Archbishop Makarios from exile. ${ }^{\mathbf{5 5}}$ Reports and recommendations were submitted to the Committee of Ministers, which decided not to take further action since the Cyprian hostilities had terminated. ${ }^{56}$ The third interState petition was received by the Commission in July of 1960 , and involves a claim by the Austrian Government that convictions of six defendants in Italian criminal proceedings violate the Convention. ${ }^{57}$

Between July 1955, when the right of individual petition was established, ${ }^{58}$ and the end of 1958, about 400 individual petitions had been received by the Commission. Of these, two cases were directly held admissible and hearings were held on the others. Of these, five were held admissible; one was settled by an offer of financial assistance..$^{59}$ In late 1959 , another individual petition was held admissible by the Commission. ${ }^{60}$

The President of the Commission has said that the high proportion of negative decisions is neither surprising nor alarming since most of the meritorious clains are remedied in the domestic forun. ${ }^{61}$ In rejecting some 277 applications the Conlmission based its decision on one or more of the following reasons. Seventy-five were lield inadmissible wholly or partly on the ground that all domestic renedies had not been exhausted, as required by article 26 of the Convention. The fault most frequently found in this category was the failure to prosecute an appeal to the domestic court of highest competence. ${ }^{62}$ Two were rejected because of failure to file the complaint withm six months after exhausting local remedies, as required

64 Docunents AND Decisions 128-30; E. Lauterpacht, The Contemporary Practice of the United Kingdom in the Field of International Law-Survey and Comment, 5 INT'x \& Coxp. L.Q. 405, 432-34 (1956).

55 The Observer (London), April 19, 1959, p. 12, col. 4.

50 The Council of Europe News, May 1959, p.3.

57 The Council of Europe News, September 1960, p. 2-3.

58 The individual petition competence of the Commission became effective only when six Members made declarations that they would be so bound. Art. 25(4).

59 Waldock, The European Convention for the Protection of Human Rights and Fundamental Freedoms, 34 BRIT. YB. INT'x L. 356, 360 (1958).

Co Nielsen v. Denmark. Nielsen was sentenced to life imprisonment on the grounds he hypnotized another and through this "somnambulist" committed robbery, attempted homicide and homicide. His petition, alleging violation of article 6(3) of the Convention, i.e., the right of an arrested person to be informed promptly and in detail of the nature of the accusation made against him, was held admissible. The Times (London), Sept. 10, 1959, p. 10, col. 5; id., July 24, 1959, p. 5, col. 6; Council of Europe News, November 1959, p. 1. The text of the Commission's decision on admissibility will be found in Council of Europe News, September 1960, p. 3.

01 Waldock, The European Convention for the Protection of Human Rights and Fundamental Freedoms, 34 BRTT. Yв. INT'x I. 356, 361 (1958).

62 Docunents ANd Decisions 136-53; McNulty and Eissen, The European Commission of Himan Rights: Procedure and Jurisdiction, 1 J. INT'x CoMm. OF JuRISTs 198, 202-05 (1958). 
by article $26 . .^{63}$ One hundred and thirteen were held inadmissible on the ground that the alleged violation had occurred before the Convention or Protocol became effective with respect to the Contracting Party ${ }^{64}$ Three were rejected on the ground that the applicant had no personal interest, ${ }^{65}$ and twenty-seven on the ground that the State involved either had not ratified the Convention or had not accepted the competence of the Commission to deal with individual petitions. ${ }^{.0}$ Six were rejected because of an abuse of the right to petition and six others on the ground that they had already been considered by the Commission. ${ }^{67}$ Twentyfive applications were held inadmissible because based on a claim to right which were not guaranteed by either the Convention or the Protocol. ${ }^{.8}$ One hundred and seventy-five were deemed inadmissible, wholly or in part, because the preliminary examination did not provide prima facie evidence of a violation. ${ }^{60}$ Thirty-five were declined because of alleged errors of fact or law of domestic tribunals that the Commission had no competence to judge. ${ }^{70}$ The number of petitions arising in this last group is expected to increase sharply as European lawyers become aware of the "Convention as a legal instrument-which could concern them."

The Commission in language reminiscent of that of the United States Supreme Court in criminal due process cases, has repeatedly maintained that it "was not set up as a higher court to examine alleged errors of law or fact committed by the domestic courts of the Contracting Parties," and that it is solely concerned with errors of domestic courts which have resulted "in violations of one of the rights and freedoms limitatively listed in the Convention."72 However, as the President of the Commission has observed, in many cases, particularly where the domestic court has applied the Convention, the Commission "may find itself almost in the position of a Court of Appeals."'73

Some of the more important petitions received by the Commission have included the petition of Rudolf Hess, the attack on the Icelandic taxation laws, and the application of the German Communist Party. The recent case brought against the Icelandic tax laws was dismissed after the Commission found that a progressive property tax was a "'permissible interference' contemplated in Article 1 of the Protocol, with a person's right to the peaceful enjoyment of his possessions." ${ }^{174}$ The petition of Rudolf Hess, who claimed his Nurenberg Trial violated the Convention, was dismissed on the alternative grounds that none of the States which tried

63 Documents and Decistons 153.

64 Id. at 153-60. The President of the Commission reports that most of the individual petitions filed against the Federal Republic of Germany "relate to acts of the Hitler régime," and are therefore madmissible. Waldock, The European Convention for the Protection of Human Rights and Fundamental Freedoms, 34 BRIT. YB. INT'L L. 356, 360 (1958).

65 DocUMMENTS AND Decisions 160-66.

66 Id. at 166-87; McNulty and Eissen, The European Commission of Human Rights: Procedure and Jurisdiction, $1 \mathrm{~J}$. INT'x COMM. OF JURISTS 198, 207-08 (1958).

67 DOCUMENTS AND DECISTONS 190-98.

68 Id. at 198-222; McNulty and Eissen, supra note 66 at 210-12.

60 DOCUMENTS AND DECISIONS $225-48$.

70 Id. at 248-58.

71 Waldock, The European Convention for the Protection of Human Rights and Futdanental Freedoms, 34 BRIT. Yв. INT'x L. 356, 361 (1958).

72 Decision 245/57 (1957), Documents and Dectstons 150, 152. See also Decision 172/56 (1956), Documents and Dectstons 211.

${ }^{73}$ Waldock, The European Convention for the Protection of Human Rights and Fundamental Freedoms, 34 BRxT. YB. INT'L L. 356, 358 (1958).

74 Council of Europe, Directorate of Information, IP/1478, HB/MM, Jan. 16, 1961. 
him had accepted the right of individual petition and that the Convention would not apply where a person was convicted for committing an act which "was criminal according to the general principles of law recognised by civilised nations."75

Of nore immediacy was the petition of two members of the German Communist Party (K.P.D.), on behalf of themselves and the Party, who claimed that the Federal Republic violated the Convention when, in 1956, the Federal Constitutional Court declared the K.P.D. to be anticonstitutional and ordered it dissolved. The petition was declared inadmissible by the Commission which reasoned that the political aims contemplated by communist ideology, whether achieved peacefully or by forceful overthrow of the existing government, were incompatible with the Convention. ${ }^{76}$ Thus, the Party was deemed to come within article 17 of the Convention, a vague provision that seems to limit the rights and freedoms of revolutionary groups in general and the Communist Party in particular, and was not able to complain that its freedoms of association and expression had been violated. "I7 "It is necessary," said the Commission, "to prevent totalitarian currents from exploiting, in their own interests, the principles enunciated by the Convention, that is, from invoking the rights of freedoin in order to suppress Human Rights."78

The legal treatment of the petitioners' rehance on the Convention is strikingly similar to the fate meted out to their American comrades who invoke certain constilutional guarantees. In both Western Europe and in the United States, the State's interest in self-preservation is being used as a rationale for a selective apportionment of basic rights and freedoms. Under both the Convention and the Constitution, the commurist is being singled out for special treatment which, in a different context, would raise "issues of the gravest character."79

\section{The Court of Human Rights}

The divergence of opmion in the Council of Europe as to the desirability of supra-national machinery to enforce international obligations that manifested itself with regard to the individual petition was also evident when the need for a Court of Human Rights was discussed. The desire to obtain ratification of the Convention by the United Kingdom led to a compromise- a court would be created, but its compulsory jurisdiction had to be accepted by the Contracting Parties independent of the Convention. ${ }^{80}$ As eight acceptances were needed under article 56, it was not until 1958 that the Court came into being when the acceptances of Austria, Iceland, and Luxembourg were added to those of Belgium, Denmark, Ireland, Germany, and the Netherlands. The first Court was chosen by the Consultative Assembly in January 1959, from a hist submitted by the Committee of Ministers and consists of three judges or ex-judges, ten law professors, two practicing law-

75 Art. 7 (2) ; Council of Europe News, January 1960, p. 9.

70 Decision 250/57 (1957), Docunents and Decisions 222; Council of Europe News, March 1957, p. 4.

${ }^{77}$ Article 17 of the Convention reads: "Nothing in this Convention may be interpreted as implying for any State, group or person any right to engage in any activity or perform any act aimed at the destruction of any rights and freedoms set forth herein or at their limitation to a greater extent than is provided for in the Convention."

78 Quoted in McNulty and Eissen, The European Commission of Human Rights: Procedure and Jurisdiction, $1 \mathrm{~J}$. INT'i Conns. OF JURISTS 198, 213 (1958).

79 Barenblatt v. United States, 360 U.S. 109, 128 (1960).

80 Art. 46. See also Robertson, The European Court of Human Rights, 9 AMr. J. Comp. L. 1, $10(1960)$. 
yers, including such legal scholars as Alf Ross of Denmark, René Cassin of France, and Lord McNair of the United Kingdom, former President of the International Court of Justice. ${ }^{81}$

The number of judges, no two of whom can be nationals of the same state, is equal to that of the Members of the Council. All Members, whether parties to the Convention or not, have an equal voice in choosing the membership of the Court. ${ }^{82}$ The judges are required to be "of high moral character and must either possess the qualifications required for appointment to high judicial office or be jurisconsults of recognised competence." ${ }^{38}$ As in the International Court of Justice, judges are chosen for a period of nine years, with selection staggered in three-year intervals. ${ }^{84}$ The Court sits in a chamber of seven, with judges who are nationals of states concerned sitting ex officio. ${ }^{85}$

After all domestic remedies have been exhausted and the Commission on Human Rights acknowledges "the failure of efforts for a friendly settlement," 86 the case is transferred to the Committee of Ministers which will make the final decision, unless within three months the case has been referred to the Court. ${ }^{87} \mathrm{~A}$ case can be referred to the Court by the Commission, the Party whose national is alleged to be a victim, the Party who referred the case to the Commission, or the Party against whom the complaint has been lodged..$^{88}$ Thus, departing from the practice of other regional tribunals, the individual has no direct access to the European Court of Human Rights. ${ }^{80}$

Owing to their relative infrequency, it is unlikely that the Court will entertain many inter-State disputes. The majority of Court cases will deal with individual petitions and these will probably come to it by reference from the Commission. ${ }^{00}$ It is doubtful that any State against whom a complaint is lodged will refer the case to the Court, for there is much less probability of an adverse decision against a

81 Council of Europe News, February 1959, p.7. The procedure for electing members of the Court is just opposite that for picking the staff of the Commission. Under article 21 the Commissioners are chosen by the Committee of Ministers from a list supplied by the Consultative Assembly, while under article 39 the Court is elected by the Assembly from a list prepared by the Committee of Ministers.

82 For example, at the present time there is a Frencl judge on the court notwithstanding France's refusal to accede to the Convention. Furthermore, it is possible to have judges elected to the Court who are not nationals of the Members in the Council of Europe. Robertson, The European Court of Human Rights, 8 INT'x \& Cosr. L.Q. 396, 399-400 (1959).

83 Art. 39(3). This follows the qualifications set forth in article 2 of the Statute of the International Court of Justice, with the deletion of the requirement of competence "in international law."

84 Compare article 40 of the Convention with article 13 of the Statute of the International Court of Justice.

85 Contrast article 43 of the Convention with article 31 of the Statute of the International Court of Justice, which permits judges who are nationals of the litigants concerned to sit in tlee case before the Court.

86 Art. 47.

87 Art. 32.

88 Art. 48.

89 Compare, for example, the Convention with the practice before the Central Commission for the Navigation of the Rhime, ROBERTSON, EUROPEAN INSTITUTIONS 116 (1959), and the new Court for the Six Power Communities, Convention Relating to Certain Institutions Common to European Communities, 5 EuROpEaN YEARBook 587-95 (1959).

00 Both cases now pending before the Court were referred by the Commission. Council of Europe News, May 1960, p. 2. See Robertson, The European Court of Human Rights, 9 Axx. J. CoMp. L. 1, 18 (1960); Bulletin of the International Commission of Jurists, No. 9, p. 6-7 (1959). 
State in the politically oriented Committee of Ministers than in the Court where legal considerations should prevail.

Article 45 of the Convention states that "the jurisdiction of the Court shall extend to all cases concerning the interpretation and application of the present Convention" which shall be referred to it. However, in contradistinction to the practice of the International Court of Justice, ${ }^{91}$ the European Court of Human Rights cannot render advisory opinions. This may be remedied, for the Consultative Assembly's Legal Comnittee has recently proposed that the conipetence of the Court be extended so that it may give advisory opinions at the request of organs of the Council of Europe. ${ }^{82}$ It is also possible that the Court of Human Rights may be made the interpretive body of all Conventions concluded under the Council of Europe as Member States have been slow to ratify a plan to submit disputes with reference to Council Conventions to the International Court of Justice. ${ }^{93}$

Under article 53, "the High Contracting Parties undertake to abide by the decision of the Court in any case to which they are parties." The judgment of the Court is transmitted to the Committee of Ministers which supervises its execution. The Committee, however, can enforce a judgment only through the mipact of adverse public opinion and the power of expulsion from the Council. ${ }^{94}$

Nevertheless, the impact of the decisions of the Court of Human Rights upon the decisional law of the domestic forum is indicative of the significant cession of sovereiguty nrade by Member States to the Court. The argument that the Court is not a court of appeals from the highest domestic tribunal, and does not have power to upset the decisions of the doniestic courts ${ }^{95}$ is "obscure and contradictory" and conceived only in "deference to emphatic protestations fron sonie delegations who regarded as utterly unacceptable the notion of decisions from the highest tribunals of their countries being questioned before a foreign tribunal."98 In fact, it seems that if an adverse judgment of the Court of Human Rights is to be given domestic effect, it must necessarily upset the judgment of the donestic court.

For example, consider the Court's first case, Lawless v. Ireland, now sub judice. ${ }^{87}$ This case involves an Irish student, Gerard Lawless, who was arrested and detained by the Irish Government for six months, without trial or charge, on suspicion of menbership in the illegal Irish Republican Army. One nonth after submitting an application to the Commission on Human Rights, Lawless was released from detention. In a suit against Ireland for damages as a result of the alleged false arrest, the Irish courts held for the governnient. The Commission concluded that the internment of Lawless was not violative of the Convention in view of the national emergency in Ireland at the tine of his arrest. After reporting its inability to achieve a friendly settlement, the Commission then referred the case

91 U.N. CHARTER art. 96.

82 Robertson, European InstTTUTIONS 26 (1959).

83 The European Convention for the Peaceful Settlement of Disputes, ch. I, in 5 EuroPEAN YEARBOOK 347-63 (1959). See Robertson, The European Court of Human Rights, 9 AMr. J. CoMrp. L. 1, 26-28 (1960); Council of Europe News, March 1960, p. 13; id., January 1961, p. 7. 84 Robertson, supra note 93 at 23 ; Boyle, International Law and Human Rights, 23 MODERN L. REV. 167 (1960).

05 Robertson, The European Court of Human Rights, 9 AMr. J. CoMrP. L. 1, 22 (1960).

$80 \mathrm{H}$. LAUTERPaCHT, INTERNATIONAL LAW AND HUMaN RIGHTS 451 (1950).

97 Council of Europe, Directorate of Information (OP 1434/bis), DL/HW, Sept. 26, 1960; The Observer (London), April 19, 1959, p. 12, col.2; The Christian Science Monitor, Oct. 8, 1960, p. 3, col. 1; Council of Europe News, January 1960, p. 8; id., March 1960, p. 2; id., May 1960, p.2. 
to the Committee of Ministers. Within three months the matter was sent to the Court.

If the Court of Human Rights decides that the arrest and detention of Lawless was a violation of the Convention and awards damages pursuant to article 5(5), the domestic judgment will necessarily be upset if Ireland gives effect to the decision of the Court. "To put it briefly, the authority of the decision of the European Court is a challenge to the authority of the Supreme Court of each Country. Any softening of that challenge, however, renders the international judicial protection of human rights, available to the individual, more or less illusory."108

\section{III}

\section{THE CONVENTION: DOMESTIC EFFECTS}

In a practical sense, the real impact of a State's international obligations upon individuals will largely depend upon the status of those obligations under domestic law. For example, the United Nations' Charter provisions on human rights ${ }^{00}$ and its Universal Declaration of Human Rights have had no direct impact on the rights of individuals, for they have been construed to impose no legal obligation upon Member Nations. ${ }^{100}$ The Convention on Human Rights, on the other hand, will have its most direct effect where national courts are bound to apply it as a part of their domestic law. In Austria, ${ }^{101}$ Belgium, ${ }^{102}$ the Federal Republic of Germany, ${ }^{103}$

98 Horvath, The Equropean Court of Human Rights, 5 O'STERRETCHISCHE ZEITSCHRTrT FÜr OFFENTIICHES RECHT 166, 180 (1953).

99 U.N. Charter art. 55, states that "the United Nations shall promote... (c) universal respect for, and observance of, buman rights and fundamental freedoms for all without distinction as to race, sex, language or rehgion." Members, according to article 56, "pledge themselves to take joint and separate action with the Organization for the achievenient of the purposes set forth in Article 55."

100 The State (Duggan) v. Tapley, [1952] Ir. R. 62, 83; Fujii v. State of California, 38 Cal. 2d 718, 242 P.2d 617 (1952); Kemp v. Rubin, 69 N.Y.S.2d 680 (Sup. Ct. 1947) ; Hudson, Charter Provisions on Human Rights in American Law, 44 Arr. J. INT'x L. 543 (1950).

However, there has been a forceful argument nuade that article 56 of the Charter imposes legal obligations our the Meniber States and that the Universal Declaration of Human Rights, while not a treaty, is an interpretation of the words, "human rights and fundamental freedoms," as contained in article 56. Wright, National Courts and Human Rights-The Fujii Case, 45 Ax. J. IvT'x L. 62, 70-72 (1951). See Black, J., concurring in Oyama v. California, 332 U.S. 633, 649 (1948); H. LAUTERPACHT, INTERNATIONAx LAW AND Human RIGHTS ch. 9 (1950).

101 Austria takes the position that whether self-executing or not, international agreements are "automatically transformed into internal law. Without further acts of transformation they brid the Austrian Administration." Seidl-Hohenveldern, Relation of International Law to Internal Law in Austria, 49 AM. J. INT'c L. 451, 460 (1955). Moreover, in Austria "a draft law has been prepared to make the Convention and Protocol part of the fundamental law of the Constitution." Counctr of Europe, Directorate of Inforaration, THE Rigats of tue EuropEAN Citizen 18 (1961).

102 Statement of Henri Rolin, now a member of the Luropean Court of Human Rights, in 30 Transact. Grot. Soc'y 31, 32 (1945). See Constitution of Belgium, article 68 in 1 PEASLEE, Constitutions of Nations 135-36 (1950); Masters, International, Law in National Courts 197-212 (1932); Preuss, On Amending the Treaty-Making Power: A Comparative Study of the Problem of Self-Executing Treaties, 51 MrCr. L. Rev. 1117, 1128 (1953). If France accepts the Convention, upon ratification it will be authority superior to that of internal legislation. Constitution of France, article 26-28, in 2 Peaslee, Constitutrons of Nations 12 (1950); Preuss, The Relation of International to Internal Law in the French Constitutional System, 44 Ax. J. INT'x L. 641 (1950).

103 O.L.G. Bremen, February 17, 1960, NEUE JURISTISCHE WochenschrIFT 1265 (1960); Decision of the Federal Administrative Supreme Court, April 10, 1956, [1956] IsT'x L. REP. 377, 379; Decision of the Administrative Court of Münster, November 26, 1955, [1955] INT'x 
Italy, ${ }^{104}$ Greece, Luxembourg, the Netherlands, ${ }^{105}$ and Turkey the Convention now has the force of domestic law. For example, in one case the German Federal Administrative Court ruled that the deportation of an alien, otherwise valid under prior law, could not be permitted because of the resultant disruption of the family in contravention of article 8 of the Convention on Human Rights. ${ }^{108}$ Consequently, in these States the individual can raise the rights and procedural guarantees set forth in the Convention in the domestic courts.

Where the national constitution does not give treaties the force of domestic law, and there is no legislative action making the Convention internally binding, the national courts will continue to give effect to local law, even though in conflict with the Convention. This is the position of Ireland, the United Kingdom, and the Scandinavian countries, where the Convention retains efficacy as a higher body of law only in appeals to the Commission and the Court of Human Rights. ${ }^{107}$

In Ireland, the constitution provides that "no international agreement shall be a part of the domestic law of the State save as may be determined by the [National Parliament] . . . "108 In 1957, an Irish court was confronted with a conflict between the domestic law and the Convention which could not be reconciled by interpretation. In applying the domestic law the court said, "[R]ules of international law are not part of domestic law, except in so far as they liave been made so. ... It is quite clear that the Convention, though the State be a party to it, cannot of itself qualify or affect our domestic legislation."109

L. Rep. 608, 609; Decision of the Administrative Court of Münster, April 13, 1954, [1954] INT'L L. Rep. 209, 210. See also Decision of the Federal Supreme Court, July 12, 1955, [1955] INT'x L. REP. 520, 523.

It is also to be noted that in Germany the Convention takes precedence over any inconsistent legislation, whether enacted prior or subsequent to its ratification. Constantopoulos, The Relation of the Law of Nations to Constitutional Law and the New Constitution of Germany, 5 Revue Heisénioue de Droit International 42, 61 (1952). The Netherlands is in accord. Netherlands Constitution, article 65 in Van Panbuys, The Netherlands Constitution and International Law, 47 Axr. J. IrT's L. 537, 553 (1953) ; Public Prosecutor v. Miss J. de B., N.J. 1954, No. 382, May 4, 1954 (Supreme Court), 2 NEDERIANDS TIJDSCHRIFT voor INTERNatToNAAL RECHT 94, 103-04 (1955); Lissitzyn, Book Review, 47 AM. J. INT'x L. 732 (1953).

104 Constitution of the Italian Republic, article 10 in 2 PEASIEE, Constriurtons of NATrons 280 (1950); Preuss, On Amending the Treaty-Making Power: A Comparative Study of Self-Executing Treaties, 51 MrcH. L. REv. 1117, 1119 (1953). Preuss states that in Italian law an international obligation will take precedence over prior and probably over subsequently enacted domestic legislation.

105 In the Netherlands the constitutional amendments of 1953 ensure the binding force of international law in prevailing over inunicipal law and authorizes the courts to test national statutes as regards their conformity with international agreements and decisions of international organizations. See Van Panhuys, The Netherlands Constitution and International Law, 47 Ax. J. INT's L. 537, 553 (1953). See also Institut etc. v. Mettes, N.J. 1956, No. 240, December 10, 1954 (Supreme Court), 4 NEDERLANDS TIJDSCHRIFT voOR INTERNatToNaAl RECHT 85 (1957); Public Prosecutor v. Miss J. de B., N.J. 1954, No. 382, May 4, 1954 (Supreme Court), 2 NederLANDS TYJDSCHRIET YOOR INTERNATIONAAI RECHT 94 (1955).

106 Decision of the Federal Administrative Supreme Court, Oct. 25, 1956, [1956] INT'x L. Rep. 393, discussed in Golsong, The European Convention for the Protection of Human Rights and Fundamental Freedoms in a German Court, 33 BRIT. Үв. INT'x L. 317 (1958).

107Beaufort, Some Remarks About the European Convention for the Protection of Human Rights and Fundamental Freedoms, 6 NEDERLANDS TIJDSCHRIFT vOOR INTERNATIONAAL RECHT 42, 44, 46 (1959); Waldock, The European Convention for the Protection of Human Rights and Findamental Freedoms, 34 BRTr. Хв. INT'2 L. 356, 358 (1958).

108 Constitution of Ireland, article 29(6), 2 Peastee, Constitutions of Nations 254 (1950). See also The State (Duggan) v. Tapley, [1952] Ir. R. 62, 83.

109 Quoted in Beaufort, supra note 107, at 45. 
Substantially the same position is taken in Great Britain, where the rule is that "when a treaty involves for its enforcement in England any change in the law administered by any English court of law ... it is necessary im order to give effect to the treaty that Parliament should enact such legislation as may be required to make that change in the law."110 But the refusal of Parliament to pass such legislation will not afford the British Government a valid international excuse for the breacli of the treaty. 111 Therefore, although the Convention cannot be relied upon in the domestic courts, it is an effective source of riglits in the international forum.

Under the law of such States as Great Britain and Ireland, the importance of the individual petition is manifest, since the individual must rely on the international forum to safeguard his rights under the Convention. ${ }^{122}$ It is significant that of the nations which do not recognize the Convention as being internally binding, all but one have recognized the individual petition jurisdiction of the Commission on Human Rights. ${ }^{113}$

\section{CONCLUSION}

The European Convention on Human Rights is a unique achievement in international law. For the Member States it stands as a workable expression of their mutual respect for the inherent dignity of the individual. Moreover, the Convention exists as a new source of domestic law, a "landmark in the change of international law into constitutional law." ${ }^{214}$ For the American observer the Convention takes on an important precedent value in the light of recent developments in the Organization of American States, which in 1959, directed the preparation of a Convention on Human Rights, with a court and a commission modeled after the European Convention for the Protection of Human Rights and Fundamental Freedoms. ${ }^{115}$

$$
\text { D.L.A.Kerson }
$$

110 McNair, When Do British Treaties Involve Legislation?, 9 BRIx. Хв. INT'L L. 59, 59-60 (1928).

111 MeNair, International Law in the Municipal Courts, 30 Transacr. Grot. Soc'y 11, 21 (1945).

112 Beaufort, Some Remarks About the European Convention for the Protection of Human Rights and Fundamental Freedoms, 6 NEDERLArsd TIJDsCHRIFT VOOR INTERNATIONAMI RECHT 42, 45 (1959).

113 I.e., Denmark, Iceland, Sweden, Norway, and Ireland.

114 Horvath, The European Court of Human Rights, 5 ÖSTERREICHISCHE ZETTSCHRIFT FüR OFFENTIICHES RECET 166, 180 (1953).

115 Resolution VIII, Fifth Meeting of Consultation of Ministers of Foreign Affairs, Santiago, Chile, August 1959. O.A.S. Official Records, OEA/Ser. C/II.5. In passing it is interesting to note the statement of the United States to Resolution VIII, "The United States, as is well known, has since its birth as a nation strongly defended human rights. The promotion of respect for human rights in the inter-American system is therefore supported by the United States. While the United States, because of the structure of its Federal Government, does not find it possible to enter into multilateral conventions with respect to human rights or with respect to an Inter-American Court of Human Rights, it, of course, raises no objection to other states' entering into conventions on these subjects should they find it possible to do so ...." Sce in general Sørensen, Federal States and the International Protection of Human Rights, 46 Axr. J. INT'x L. 195 (1952).

The European Convention has already been incorporated in part in the Nigerian Constitution, and may become the model for an African Convention on Human Rights. CouncIr of Europe, Directorate of Information, The Rights OP the European Cimizen 23 (1961). 